\title{
Characteristics of Negro College Chief Librarians
}

\author{
BY FRANCES M. POLLARD
}

WITHIN what circumstances do academic librarians move rapidly to the position of chief librarian? One answer, indicated by a 1961 survey, is as a Negro in the South.

This article is based on a study which compared selected characteristics of two groups of chief librarians who were employed during the academic year 1960-61 in four-year, degree-granting institutions with enrollments below five thousand. All of the institutions were either members of the Southern Association of Colleges and Secondary Schools, or had been granted approved status by the association. ${ }^{1}$ Of these colleges, 143 were white and 57 were Negro. ${ }^{2}$ The information reported here was obtained from questionnaires returned by ninety, or 63 per cent, of the white chief librarians, and fifty-one, or 91 per cent, of the Negro chief librarians.

Basically, the original study sought answers to the following questions: Who are the Negro college chief librarians? What are their characteristics with respect to: (1) age, sex distribution, and birthplace; (2) extent and type of academic and professional education; and (3) extent of professional library experience? How do Negro college chief librarians compare in these characteristics with their white counterparts? Are the differences observed between Negro and white chief librarians significant?

Several considerations led to these questions. Negro college chief librarians,

\footnotetext{
${ }^{1}$ Southern Association of Colleges and Secondary Schools, List of Member Universities and Colleges of the Association, December 1, 1960 (Atlanta, Georgia: 1960).

${ }^{2}$ As one Negro college was part of a university system and did not employ a separate chief librarian, the number was actually 56 .
}

Dr. Pollard is Administrative Assistant in the Eastern Illinois University Library in Charleston.

for the most part, perform their occupational roles in communities where the dual system of education for whites and Negroes still persists. They have minority status within a biracial organization in which the two components are theoretically separate but equal. If equality actually existed, there would remain the implication of inferiority and difference because of segregation. ${ }^{3}$

The varying patterns of segregation in southern communities result in corresponding variations in opportunities for association between white and Negro professional groups. For Negro college librarians opportunities for professional association within the southern area range from interracial professional association to segregated professional association to relative professional isolation. Generally the Negro college librarian operates against, or rather behind, a backdrop of color.

This situation held implications for a study of the characteristics of Negro college chief librarians. In the first place, there were those factors which led one to expect to find that the Negro college chief librarians did not have qualifications equal to those of white college chief librarians. The nature of the biracial organization with its segregated school systems, the excessive costs involved in the

${ }^{3}$ E. Franklin Frazier, Race and Culture Contacts in the Modern World (New York: Knopf, 1957), p. 286. 
attempt to maintain two systems, and the minority status occupied by the Negro college chief librarians suggested difference and inequality.

On the other hand, the recognition of the importance of accreditation to the colleges in which the Negro chief librarians worked, consideration of the related effects of the qualitative standards of the Southern Association and the ALA, and the interest of librarians in achieving the status of a full-fledged profession, suggested a counter tendency toward standardization and equality. These factors indicated that the tendencies toward difference and inequality which were anchored in the culture might be minimized by the impact of professional standards.

The report presented detailed information on the characteristics of the Negro and white chief librarians. Attention is focused here on the differences which were revealed through a statistical analysis and comparisons of those characteristics.

\section{Significant Differences}

The difference in age between whites and Negroes was significant. Negro chief librarians were younger than the whites. This finding has more meaning when it is considered along with two others which are related: (1) The Negroes were appointed at an earlier age to the chief librarian positions which they held at the time of the survey; and (2) they had worked as librarians for fewer years before their appointments.

The demand in the South for professionally-educated Negro college librarians is such that they do not have to wait as long as the whites before becoming chief librarians. The Negroes have not lived as long as the whites before achieving this position, and they also have had less library experience. It appears that this is an instance in which the segregated system influences the comparatively rapid advancement of the Negro college librarian, as experience is one of the qualifica- tions considered important in the selection of chief librarians. There is the suggestion that, if the Negroes and the whites were selected without consideration for race, the Negro college librarians would have to wait longer than they do now before becoming administrators.

The difference between Negroes and whites who were born in the southern area was also significant. More Negroes than whites were southern-born. Thirtythree per cent of the whites, compared with 16 per cent of the Negroes, were born outside of the South. Judging from this, it appears that the South is less attractive to Negroes who are born outside of the region than it is to whites. There was also an indication of a tendency for more southern-born Negroes than whites to remain in the South, possibly because of the opportunities available in Negro college libraries in southern states.

Significant differences were found between white and Negro chief librarians with respect to the extent of academic and professional education. The Negroes had placed more emphasis than the whites on achieving the master's degree in library science, while the white librarians to a greater extent than the Negroes had emphasized the master's degree in an academic subject. While the master's degree in library science is the basic professional degree, an advanced degree in an academic subject is one of the standards recommended by the ALA. College librarians are expected to do graduate work in areas which will contribute to their effectiveness and, in some instances, such study may lead to a second or third master's degree rather than to $\mathrm{a} \mathrm{PhD}$ degree. The differences obtained from the comparisons of extent of academic and professional education were therefore viewed as indicators of preference rather than differentials in extent of preparation.

Th Negro chief librarians of this report possessed the professional and academic education required by their positions. Within the total group of fifty-six 
Negro respondents and nonrespondents, forty-five, or 80 per cent, held master's degrees in library science. Eleven, or 20 per cent, held the bachelor's degree in library science. Thus no Negro chief librarian was found to be without a professional degree.

In addition, there were eight librarians in the Negro population with advanced academic degrees. These included one $\mathrm{PhD}$ degree in a subject field and one D Ed. degree.

\section{INSIGNIFICANT DIFFERENCES}

Analyses of data relating to: (1) sex distribution; (2) type of professional education; and (3) type of academic education revealed no significant differences.

The type of professional education was determined by whether or not the MLS degree had been obtained from an accredited library school, and whether or not the school was located in the South. No significant difference was found between whites and Negroes holding master's degrees from accredited library schools. Most of the whites and Negroes selected for professional education those institutions which had been accredited by the ALA, and more than 60 per cent of each group chose library schools located outside of the South.

The greater preference expressed by the white college chief librarians for library schools outside of the South is of especial interest when one considers that there are ten accredited library schools located in the South and that only one of these is devoted primarily to the education of Negro librarians. The Negroes also preferred library schools located elsewhere instead of the one school primarily available to them in the southern region.

Within each group, white and Negro, there was no significant difference between men and women chief librarians with respect to the choice of an accredited library school or the geographical location of the school.

In the choices of undergraduate majors and minors, two of the criteria used to determine the type of academic education, no significant differences were noted between white and Negro librarians. As undergraduate majors and minors, the whites preferred the humanities, the social sciences, science and mathematics, and education and psychology, in that order. The Negroes expressed preferences in the following order: humanities, social sciences, education and psychology, and science and mathematics.

The majority of the white and Negro librarians entered the field of librarianship with undergraduate backgrounds in the humanities and the social sciences. This finding is in agreement with the general recommendation that persons wishing to become librarians should have a strong liberal arts background.

The analysis of choices of locations of undergraduate colleges revealed no significant differences between whites and Negroes. Predominantly, the white and Negro librarians were products of southern colleges. This is not unusual in view of the fact that two-thirds of the whites and 84 per cent of the Negroes were born in the southern states. This finding can be interpreted as a factor which would tend to bring the whites and Negroes closer together in the quality of undergraduate education than would be the case, for example, if most of the whites had received undergraduate education outside of the South. It has been generally recognized that the quality of education in the South, for whites as well as Negroes, has been lower than the national norm.

In regard to experience, there was significant difference between whites and Negroes in the number of years worked as a professional librarian before appointment to the position held at the time of the survey. But when experience was considered in terms of the number of libraries in which the respondents had worked prior to the present appointment, and the number of years they had held 
their present positions, the difference was not significant. This means that the greater experience found for the white librarians in terms of total number of years worked as a professional librarian before the present appointment did not necessarily indicate movement from one library to another or the number of years of experience in the present position.

\section{CONCLUSION}

The effects of professionalization and standardization were reflected in the educational preparation of the Negro chief librarians. To a great extent, they had received professional education from the same accredited library schools as the whites, and they had become full-fledged members of an occupation not yet fully professionalized but one that is moving along the continuum of professionalism.

Achievement of this status by Negro librarians has resulted from a combination of efforts: (1) to improve Negro colleges and their libraries, so that they might compare favorably with colleges and college libraries in general; (2) to prepare professionally educated Negro librarians to staff the college libraries; and (3) to meet standards for college libraries and librarians, as they have been set forth by the Southern Association and the ALA.

Although Negroes entered the field of librarianship later than whites, and although Negro college library development lagged behind that of college libraries in general, there have been persistent efforts, especially since 1925 , to develop a body of professionally educated Negroes for the occupation of librarian. It is important to note that the strides which have been made in this direction were not fostered primarily by Negroes themselves. In a large measure, the financial support for library education for Negroes in the South and the leadership from the library profession came through the sponsorship of white philanthropic foundations and white leaders in both the fields of education and librarianship. Negro men and women have been eager to enter the field of librarianship and to take advantage of the opportunities for professional education. The findings of this investigation reflect this combination of efforts.

\section{NEW AND FUTURISTIC . . .}

\section{(Continued from page 268)}

the technical services than there are to aid the reader services. Yet, at least one kind of machine appears to be most useful in the technical services operations. Punched tape typewriters, such as the Flexowriter, are invaluable in library order and processing work. Moreover, punched tape typewriters have been found to be particularly useful when wedded to a random access computer, as has been done at the Hanford Atomic Energy Works library in Richland, Washington.

Finally, one basic service for nurturing automation is not yet on the market. Eyes are focused on the Library of Congress, expectantly waiting to see the initiation of the distribution of Library of Congress catalog cards on magnetic tape. This is a possible service which has been discussed for some time among librarians interested in automation. When this service is perfected, electronic computers can produce for libraries on demand catalog cards untouched by human hands. Unquestionably, among the first subscribers for this new service will be the libraries of the new colleges and universities. 